\title{
Effect of Industrial and Distillery Effluents on Spodoptera litura
}

\author{
Shreya Handa*, Meena Thakur and S.K. Bhardwaj \\ Department of Environmental Science, Dr Y S Parmar University of Horticulture and \\ Forestry, Nauni, Solan, India \\ Department of Entomology, Dr Y S Parmar University of Horticulture and Forestry, Nauni, \\ Solan, India \\ *Corresponding author
}

A B S T R A C T

\section{Keywords \\ Heavy metal, Effluent, Heavy metal accumulation \\ Article Info \\ Accepted: \\ 26 August 2018 \\ Available Online: \\ 10 September 2018}

"Effect of industrial and distillery effluents on Spodoptera litura" was carried out during 2015-2016 in pot experiment in the experimental farm of Department of Environmental Science, Dr Y. S. Parmar University of Horticulture and Forestry, Nauni, Solan which is located at an altitude of $1273 \mathrm{~m}$ amsl and at latitude of $35.5^{\circ} \mathrm{N}$, longitude of $77.8^{\circ} \mathrm{E}$. The experiment comprised of 4 treatments viz., $\mathrm{T}_{1}(75 \%), \mathrm{T}_{2}(50 \%), \mathrm{T}_{3}(25 \%)$ and $\mathrm{T}_{4}$ (control, pond water). The $\mathrm{As}, \mathrm{Cd}, \mathrm{Cr}, \mathrm{Cu}, \mathrm{Fe}, \mathrm{Ni}, \mathrm{Pb}$ and $\mathrm{Hg}$ content in the $6^{\text {th }}$ instar of Spodoptera litura varied, respectively. Larvae of $S$. litura were unable to complete their life cycle when fed on leaves of $S$. lycopersicum irrigated with treatments $T_{1}$. Pupal and adult deformities were observed in treatments $\mathrm{T}_{2}$.

\section{Introduction}

Water has become of serious economic, social and political concerns since last two decades due to its reduced availability and requirement in various sectors. Due to water scarcity, agricultural activities (using more than 50\% of the total water resource extracted) are penalized. Irrigation of crops with effluents is a very common practice in India due to scarcity of water for irrigation (Sharma et al., 2007; Arora et al., 2008). Effluent is defined as wastewater treated or untreated that flows out of a treatment plant, sewer or industrial outflow (USEPA, 2006). There are beneficial and damaging effects of wastewater irrigation on crops including vegetables (Ramana et al.,
2002; Saravanamoorthy and Ranjitha-Kumari, 2007). Tomato (Lycopersicon esculentum Mill.) is one of the most widely grown crops in the world, with global tomato production exceeding 141 million tonnes $\mathrm{yr}^{-1}$ (FAOSTAT, 2009). Heavy metals may move on to other organisms and through biomagnification enter in to food chain. Because insect behaviours are key contributors to the ecology of insect interactions with other plant and animal species, as well as with their abiotic environments, these behaviours are critical to the stability and diversity of ecosystems (Fishers, 1998). Among various insect pests attacking vegetable crops, Spodoptera litura Fabricius (Tobacco caterpillar) is cosmopolitan and polyphagous pest affecting 
several crops like cotton, pulses, oilseed, vegetables, etc. all over the world and causing loss of agricultural production.

\section{Materials and Methods}

Four to five week old seedlings of tomato (Solanum lycopersicum) variety-Solan Lalima were procured from the Department of Vegetable Science, Dr Y.S. Parmar university of Horticulture and Forestry, Nauni-Solan, H.P. and planted in pots of $16 \mathrm{~kg}$ capacity in the month of April. The pots were filled with planting materials i.e. sand, soil and FYM in the ratio 1:1:1. The seedlings were irrigated daily with pond water until their establishment. The seedling took approximately one month for the establishment. Industrial and distillery effluents were collected from industrial area Paonta Sahib (Jaimurti chemical Pvt Ltd), Sirmourand Mohan mekin distillery, Chamba Ghat, Solan and quality parameters studied. It was diluted with water for preparing working concentrations. The quantity of effluent treatments required per pot was standardized according to the capacity of the soil per pot. The whole set of experiment was laid in three replications. The effluent treatments were given twice in every week for 3 months, after the establishment of the seedlings.

\section{Analysis of effluent for quantity parameters}

$\mathrm{pH}$ was estimated in 1:2 soil water suspension (Jackson, 1973) by using microprocessor based pH meter (Model 510 of EIA make), turbidity was measured by using nephlometeric turbidity meter and expressed as (NTU) nephlometric turbidity unit; electrical conductivity and total dissolved solids (TDS) were measured by microprocessor based conductivity meter (Model-1601 EIA make), alkalinity of the effluents was recorded by using titration method, BOD was estimated by 5 day BOD test as per 5210 B method (APHA, 2011); COD was estimated by oxidizing the effluent sample with hot $\mathrm{H}_{2} \mathrm{SO}_{4}$ solution of potassium chromate with silver sulphate as the catalyst by using closed reflux colorimetric method as per 5220 D method (APHA, 2011). The effluent samples were filtered with Whatman filter paper (No. 1). The samples for detection of heavy metal were prepared as per the digestion method of US-EPA 3050 B method (APHA, 2011) and estimated by using Inductively Coupled Plasma Emission Spectrometer-6300 DUO (ICAP-6300 Duo) and concentration expressed as $\mathrm{mg} \mathrm{kg}^{-1}$. Except COD, TDS and Ni content all other parameters were above permissible level in industrial effluents, whereas in pond water which was used as control all the quality parameters except turbidity and mercury $(\mathrm{Hg})$ content were below permissible level (Table 1). Therefore, the industrial effluent was further diluted to $75 \%, 50 \%$ and $25 \%$ and there concentrations used in the study.

\section{Effect of effluent irrigation of tomato crop on Spodoptera litura (Tobacco caterpillar)}

The studies were conducted with the same set of experiment. Adults of S. litura collected manually from the field reared under laboratory conditions on castor leaves. For the study, freshly hatched larvae (10 larvae) were reared on tomato leaves collected from the plants treated with different effluent concentrations. The larval, pupal, adult and total developmental period, and any deformation during the life cycle of S. litura were recorded for each treatment.

\section{Statistical analysis}

The data generated in the study was analysed by using standard statistical procedure through CRD (Completely Randomised Design) as per method described by Cochran and Cox (1963). 


\section{Results and Discussion}

Effect of industrial and distillery effluent treatments on total developmental period and heavy metals in $S$. litura infesting tomato crop

The incubation period and different developmental stages of $S$. litura which was reared under laboratory conditions on leaves of tomato plants, which were given different effluent treatments are presented in Table 2 and 3.

The incubation period in the treatments varied from 2.66 $\pm 0.33\left(\mathrm{~T}_{1}\right.$ and $\left.\mathrm{T}_{3}\right)$ to $3.33 \pm 0.33\left(\mathrm{~T}_{2}\right)$ days. The incubation period in treatment $\mathrm{T}_{2}$ (50\%) was greater than that in $\mathrm{T}_{4}$ (control). The larvae in treatments $\mathrm{T}_{1}$ (75\% of industrial effluent) were not able to complete their normal larval period. Highest total larval period was recorded at treatment $\mathrm{T}_{2}(50 \%$ of industrial effluent, 20.63 \pm 2.33 days) whereas, lowest total larval period (18.29 \pm 2.33 days) was recorded in treatment $\mathrm{T}_{3}(25 \%$ of industrial effluent).

In control $\left(\mathrm{T}_{4}\right)$ the total larval period was of $19.99 \pm 2.33$ days there was increase in total larval period at 50 per cent concentration of industrial and 75 per cent of industrial effluent as compared to control. Treatments $\mathrm{T}_{3}$ had higher pupal period than the control. No developmental period was recorded at treatments $\mathrm{T}_{1}$ (75\% of industrial effluent), respectively. In control the total developmental period was of $24.99 \pm 3.47$ days.

In Table 3, the incubation period in the treatments varied from $2.66 \pm 0.33$ to $3.00 \pm 0.00$ days. Lowest incubation period of $2.66 \pm 0.33$ days was recorded at treatments $\mathrm{T}_{1}(75 \%$ of distillery effluent), $\mathrm{T}_{2} \quad(50 \%$ of distillery effluent) and $\mathrm{T}_{3}$ (25\% of distillery effluent). Whereas, highest incubation period of $3.00 \pm 0.00$ days was recorded at treatment $\mathrm{T}_{4}$ (control, pond water). Thus there was decrease in incubation period as compared to control $\left(\mathrm{T}_{4}\right)$ except for the treatments viz., $\mathrm{T}_{2}(50 \%$ of industrial effluent) having $3.33 \pm 0.33$ days as compared to $3.00 \pm 0.00$ days in control. Highest total larval period was recorded at treatment $\mathrm{T}_{4}$ (control, pond water) whereas, lowest total larval period (18.29 \pm 2.33 days) was recorded in treatment $\mathrm{T}_{2} \quad(50 \%$ of distillery effluent). Highest pupal period was recorded in treatment $\mathrm{T}_{1}(75 \%$ of distillery effluent) whereas, lowest $(7.33 \pm 0.33$ days $)$ was recorded in treatment $\mathrm{T}_{3}(25 \%$ of distillery effluent), respectively. Treatments $\mathrm{T}_{1}$ had higher pupal period than the control. In control the total developmental period was of $24.99 \pm 3.47$ days

The data presented in Table 3 shows the effect of distillery effluent on status of heavy metals in sixth instar of Spodoptera litura. The arsenic content in the body of $S$. litura ranged from 0.02 to $0.10 \mathrm{ppm}$, highest $(0.10 \mathrm{ppm})$ was recorded at treatment $\mathrm{T}_{1} \quad(75 \%$ of distillery effluent). Whereas, lowest As content $(0.02 \mathrm{ppm})$ was recorded in $\mathrm{T}_{3}(25 \%$ of distillery effluent) which was statistically at par with all other treatments except T1 (75\% of distillery effluent), respectively. The $\mathrm{Cd}$ values ranged from 0.02 to $0.10 \mathrm{ppm}$.

Highest Cd content $(0.10 \mathrm{ppm})$ was recorded in treatment $\mathrm{T}_{1}(75 \%$ of distillery effluent) whereas, lowest $\mathrm{Cd}$ content $(0.02 \mathrm{ppm})$ was recorded at treatments $\mathrm{T}_{4}$ (control, pond water). The chromium $(\mathrm{Cr})$ content varied from 0.05 to $0.82 \mathrm{ppm}$. Highest $\mathrm{Cr}$ content $(0.82 \mathrm{ppm})$ was recorded at $\mathrm{T}_{1}(75 \%$ of distillery effluent) whereas, statistically lowest Cr content $(0.05 \mathrm{ppm})$ recorded at $\mathrm{T}_{4}$ (control), respectively. Statistically, $\mathrm{Cu}$ content was recorded highest $(8.40 \mathrm{ppm})$ at treatment $\mathrm{T}_{1}$ (75\% of distillery effluent) whereas, lowest $\mathrm{Cu}$ content of $2.52 \mathrm{ppm}$ was recorded at $\mathrm{T}_{4}$ (control), respectively. The iron $(\mathrm{Fe})$ content varied from 2.20-15.70 ppm. 
Table.1 Physico-chemical characteristics of industrial and distillery effluents

\begin{tabular}{|l|l|l|l|l|}
\hline \multicolumn{1}{|c|}{ Parameters } & \multicolumn{1}{|c|}{$\begin{array}{c}\text { Industrial } \\
(\mathbf{1 0 0 \% )}\end{array}$} & $\begin{array}{c}\text { Distillery } \\
(\mathbf{1 0 0 \%})\end{array}$ & $\begin{array}{c}\text { Control } \\
\text { (pond water) }\end{array}$ & $\begin{array}{c}\text { Permissible } \\
\text { levels }\end{array}$ \\
\hline pH & 6.72 & 6.84 & 6.50 & 6.5 \\
\hline Turbidity (NTU) & 34.99 & 11.67 & 10.62 & 1.0 \\
\hline EC (dSm $\left.{ }^{-1}\right)$ & 2.19 & 1.19 & 0.36 & 2.0 \\
\hline TDS (mg/l) & 175.20 & 75.20 & 88.32 & 1300 \\
\hline Alkalinity (mg/l) & 355.00 & 387.00 & 198.00 & 200 \\
\hline BOD & 33.00 & 30.00 & 20.00 & 20 \\
\hline COD & 248.00 & 74.00 & 141.00 & 250 \\
\hline As (ppm) & 0.25 & 0.10 & 0.02 & 0.2 \\
\hline Cd (ppm) & 0.25 & 0.22 & 0.07 & 0.03 \\
\hline Cr (ppm) & 1.17 & 1.87 & 0.07 & 0.3 \\
\hline Cu (ppm) & 7.35 & 6.35 & 0.05 & 1.0 \\
\hline Fe (ppm) & 26.69 & 29.45 & 0.22 & 0.3 \\
\hline Ni (ppm) & -1.20 & -1.02 & 0.07 & 0.2 \\
\hline Pb (ppm) & 0.60 & 0.57 & 0.05 & 0.1 \\
\hline Hg (ppm) & 8.87 & 8.57 & 0.30 & 0.005 \\
\hline
\end{tabular}

Table.2 Effect of effluent treatments on total developmental period of S. litura infesting tomato crop

\begin{tabular}{|c|c|c|c|c|c|c|c|c|c|c|c|c|}
\hline \multirow[t]{2}{*}{ Treatments } & \multirow{2}{*}{$\begin{array}{l}\text { Incuba } \\
\text { tion } \\
\text { period } \\
\text { (days) }\end{array}$} & \multirow{2}{*}{$\begin{array}{l}\text { Total } \\
\text { larval } \\
\text { period } \\
\text { (days) }\end{array}$} & \multirow{2}{*}{$\begin{array}{l}\text { Pupal } \\
\text { period } \\
\text { (days) }\end{array}$} & \multirow{2}{*}{$\begin{array}{c}\text { Total } \\
\text { development } \\
\text { al period } \\
\text { (days) }\end{array}$} & \multicolumn{8}{|c|}{ Heavy metals (mg/l) } \\
\hline & & & & & As & Cd & $\mathrm{Cr}$ & $\mathbf{C u}$ & $\mathrm{Fe}$ & Ni & $\mathbf{P b}$ & $\mathrm{Hg}$ \\
\hline $\begin{array}{l}\mathrm{T}_{1} \text { (Industrial } \\
\text { effluent75\%) }\end{array}$ & $\begin{array}{l}2.66 \pm 0 . \\
33\end{array}$ & - & - & - & $\begin{array}{l}0.0 \\
7\end{array}$ & $\begin{array}{l}0.0 \\
7\end{array}$ & $\begin{array}{l}0.5 \\
5\end{array}$ & $\begin{array}{l}3.6 \\
0\end{array}$ & $\begin{array}{l}19.6 \\
0\end{array}$ & $\begin{array}{l}0.0 \\
2\end{array}$ & $\begin{array}{l}0.7 \\
7\end{array}$ & $\begin{array}{l}1.0 \\
0\end{array}$ \\
\hline $\begin{array}{l}\mathrm{T}_{2} \text { (Industrial } \\
\text { effluent } 50 \% \text { ) }\end{array}$ & $\begin{array}{l}3.33 \pm 0 . \\
33\end{array}$ & $\begin{array}{l}20.63 \pm 2 . \\
33\end{array}$ & $\begin{array}{l}7.66 \pm 0.5 \\
7\end{array}$ & $24.97 \pm 3.47$ & $\begin{array}{l}0.0 \\
5\end{array}$ & $\begin{array}{l}0.0 \\
5\end{array}$ & $\begin{array}{l}0.4 \\
5\end{array}$ & $\begin{array}{l}3.3 \\
3\end{array}$ & $\begin{array}{l}16.7 \\
0\end{array}$ & $\begin{array}{l}0.0 \\
1\end{array}$ & $\begin{array}{l}0.5 \\
7\end{array}$ & $\begin{array}{l}0.8 \\
2\end{array}$ \\
\hline $\begin{array}{l}\mathrm{T}_{3} \quad \text { (Industrial } \\
\text { effluent } 25 \% \text { ) }\end{array}$ & $\begin{array}{l}2.66 \pm 0 . \\
33\end{array}$ & $\begin{array}{l}18.29 \pm 2 . \\
33\end{array}$ & $\begin{array}{l}10.00 \pm 0 . \\
33\end{array}$ & $26.29 \pm 3.47$ & $\begin{array}{l}0.0 \\
4\end{array}$ & $\begin{array}{l}0.0 \\
5\end{array}$ & $\begin{array}{l}0.4 \\
2\end{array}$ & $\begin{array}{l}3.3 \\
0\end{array}$ & $\begin{array}{l}16.4 \\
2\end{array}$ & $\begin{array}{l}0.0 \\
1\end{array}$ & $\begin{array}{l}0.5 \\
2\end{array}$ & $\begin{array}{l}0.5 \\
5\end{array}$ \\
\hline $\begin{array}{l}\mathrm{T}_{4} \text { (Control, } \\
\text { pond water) }\end{array}$ & $\begin{array}{l}3.00 \pm 0 . \\
00\end{array}$ & $\begin{array}{l}19.99 \pm 2 . \\
33\end{array}$ & $\begin{array}{l}8.00 \pm 0.5 \\
7\end{array}$ & $24.99 \pm 3.47$ & $\begin{array}{l}0.0 \\
2\end{array}$ & $\begin{array}{l}0.0 \\
2\end{array}$ & $\begin{array}{l}0.0 \\
5\end{array}$ & $\begin{array}{l}2.5 \\
2\end{array}$ & 2.20 & $\begin{array}{l}0.0 \\
2\end{array}$ & $\begin{array}{l}0.0 \\
2\end{array}$ & $\begin{array}{l}0.1 \\
0\end{array}$ \\
\hline CD (0.05) & & & 0.01 & & & $\begin{array}{l}\text { 0.0 } \\
3\end{array}$ & $\begin{array}{l}0.1 \\
9\end{array}$ & $\begin{array}{l}1.6 \\
9\end{array}$ & 2.03 & $\begin{array}{l}0.0 \\
1\end{array}$ & $\begin{array}{l}1.1 \\
0\end{array}$ & $\begin{array}{l}0.4 \\
1\end{array}$ \\
\hline
\end{tabular}

* Pupal and Adult deformities observed 
Table.3 Effect of effluent treatments on total developmental period and status of heavy metals in sixth instar of Spodoptera litura infesting tomato crop

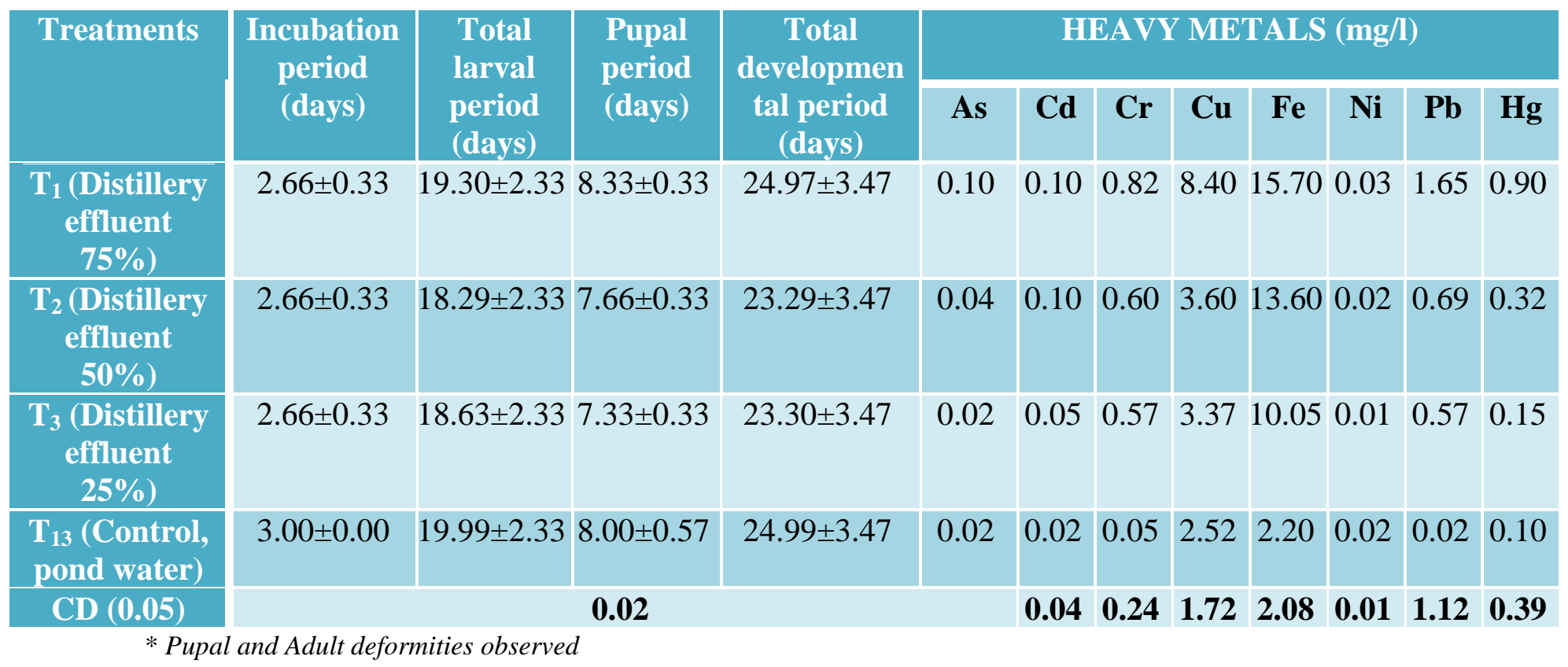

Highest Fe content $(15.70 \mathrm{ppm})$ was recorded at treatment $\mathrm{T}_{1} \quad(75 \%$ of distillery effluents) whereas, statistically lowest Fe content $(2.20$ ppm) was recorded at treatment $\mathrm{T}_{4}$ (control, pond water), respectively. The nickel $(\mathrm{Ni})$ content in the sixth instar of $S$. litura ranged from 0.00 to $0.02 \mathrm{ppm}$. Highest $\mathrm{Ni}$ content $(0.03$ ppm) was recorded at treatment $\mathrm{T}_{1}(75 \%$ of distillery effluent) which was statistically at par with treatment $\mathrm{T}_{4}$ (control, pond water, 0.03 $\mathrm{ppm})$ whereas, lowest $\mathrm{Ni}$ content $(0.00 \mathrm{ppm})$ which was statistically at par with treatment $\mathrm{T}_{2}$ (50\% of distillery effluent, $0.02 \mathrm{ppm}$ ) and $\mathrm{T}_{4}$ (25\% of distillery effluent, $0.02 \mathrm{ppm})$, respectively. The lead $(\mathrm{Pb})$ content ranged from 0.02 to $1.65 \mathrm{ppm}$.

Highest $\mathrm{Pb}$ content $(1.65 \mathrm{ppm})$ was recorded at treatments $\mathrm{T}_{1}$ (75\% of distillery effluent) whereas, lowest $\mathrm{Pb}$ content $(0.02 \mathrm{ppm})$ was observed at $\mathrm{T}_{4}$ (control, pond water), respectively. The mercury $(\mathrm{Hg})$ contents ranged from 0.10 to $0.90 \mathrm{ppm}$. Highest $\mathrm{Hg}(0.90 \mathrm{ppm})$ was recorded at treatment $\mathrm{T}_{1}$ (75\% of distillery effluent) whereas, lowest $\mathrm{Hg}(0.10 \mathrm{ppm})$ was recorded at $\mathrm{T}_{4}$ (control, pond water), respectively. The present findings are in confirmation with the findings of Sildanchandra and Crane, (2000) who reported that high $\mathrm{Cd}$ concentration increases the larval duration of holometabolous insects. Significant prolongation of gypsy moth larval development was obtained after acute or chronic exposure to $\mathrm{Cd}$ at a concentration of $100 \mu \mathrm{g} / \mathrm{g}$ (Ortel et al., 1993; Gintenreiter et al., 1993; Ilijin et al., 2010). According to Barbosa et al., (1983) chronic exposure of gypsy moth larvae to $\mathrm{Cd}$ or unstable host plant led to decrease in pupal duration.

These findings are in confirmation with the findings of Smith et al., (2004) who observed that Zn@5mg Zn/dry food led to increase of developmental period of Falsomia candida. Zheng- Tian et al., (2011) reported that $\mathrm{Cd}$ in food significantly led to increase in developmental period of Pirata sub piraticus. Heliovaara et al., (1987) who reported that heavy metal concentrations in Araduscin namomeus were highest (Cd $17 \mu \mathrm{g} \mathrm{g}^{-1}, \mathrm{Cu} 1900$ $\mu \mathrm{g} \mathrm{g}^{-1}$, Ni $202 \mu \mathrm{g} \mathrm{g}^{-1}, \mathrm{~Pb} 32 \mu \mathrm{g} \mathrm{g}^{-1}$ ) in the vicinity of the factor complex, and lowest in the 
outermost zones. Variation in contents of various heavy metals in the body of $6^{\text {th }}$ instar larvae of $S$. litura was observed in the present study. The insect was fed on tomato leaves irrigated with effluents containing varied heavy metal content with $\mathrm{Pb}$ and $\mathrm{Hg}$ above the permissible levels in some treatments of higher concentration. Studies on movement of heavy metals from the host plant to the herbivore level are reported (Vogel, 1986; Zvereva et al., 2003). Insects living in polluted areas have shown accumulation of heavy metals particularly $\mathrm{Ni}$ and $\mathrm{Cu}$ (Zvereva et al., 2003). Absorption of $\mathrm{Cd}$ and $\mathrm{Hg}$ by crops and accumulation in insects through food chain is reported (Devkota and Schmidt, 2000; Pedersen et al., 2008) which supports the present findings of higher $\mathrm{Cd}$ and $\mathrm{Hg}$ levels as compared to control. Some levels of mineral elements are already present in the insect body e.g. $\mathrm{Na}, \mathrm{K}$, $\mathrm{Ca}, \mathrm{Mg}, \mathrm{Fe}, \mathrm{Zn}, \mathrm{Cu}$ and $\mathrm{Mn}$ in the level of 10.6, $30.2,5.2,15.9,0.40,0.68,0.20$ and 0.86 $\mathrm{mg} / 100 \mathrm{~g}$, respectively are found in the body of white grubs normally. No nickel content was detected in effluents, soil and leaves of tomato fruit but in the larval body nickel content of 0.01-0.03 ppm was found, which could be normally present in its body. Accumulation of nickel in the body of Spodoptera $6^{\text {th }}$ instar larvae when fed on artificially amended $\mathrm{Ni}$ diet has been reported Xia et al., (2007). Biomagnifications of mercury $(\mathrm{Hg})$, cadmium $(\mathrm{Cd})$ and lead $(\mathrm{Pb})$ through soil-plant, herbivorous insect and carnivorous insect food chain i.e. $0.18,6.57,7.88$, for mercury: 6.82 , 2.01, 0.48 and for cadmium: 1.47, 2.24 and 0.57 , respectively has been investigated (Sheng Zhang et al., 2009).

\section{References}

APHA 2011. Standard methods for examination of water and wastewater. $20^{\text {th }}$ ed. American Public Health Association, American water works association and water environment federation, Washington, DC New York.

Arora M, Kiran B, Rani A, Rani S, Kaur B and Mittal M. 2008. Heavy metal accumulation in vegetables irrigated with water from different sources. Food Chemistry 111: 811-815.

Barbosa P, Waldowogel M, Martinat $\mathrm{P}$ and Douglas L W. 1983. Developmental and reproductive performance of the gypsy moth, Lymantriadispar (L.) (Lepidoptera: Lymantriidae) on selected hosts common to mid- Atlantic and southern forests. Environmental Entomology 12: 18581862.

Cochran G C and Cox G M. 1963. Experimental designs. Asia publishing house, Bombay. $611 \mathrm{p}$.

Devkota B and Schmidt G H. 2000. Accumulation of heavy metals in food plants and grasshoppers from Taigetos Mountains Greece. Agriculture, Ecosystems and Environment, 78:85-91.

FAOSTAT. 2009. http://www.Faostat.fao. org/site/567/Desktopdefeult.aspx?PageID $=567$ \#ancor

Fisher B L. 1998. Insect behavior and ecology in conservation: preserving functional species interactions. Annals of the Entomological Society of America 91:155-158.

Gintenreiter S, Ortel J and Nopp H J. 1993 a. Bioaccumulation of cadmium, lead, copper and zinc in successive developmental stages of Lymantria dispar L. (Lymantriidae, Lepidoptera)-a life cycle study. Archives of Environmental Contamination and Toxicology 25: 55-61.

Heliovaara K, Vaisanen R, Braunschweiler H and Lodeius M. 1987. Heavy metals level in two biennial pine insects with sap sucking and gall-forming life stages. Environmental Pollution 48: 13-23.

Ilijin L, Mataruga V, Radojicic R, Lazarevic J, Nenadovc V, Vlahovic $M$ and Mrdakovic M. 2010. Effects of cadmium on protocerebral neurosecretory neurons and fitness components in Lymantriadispar L. Folia Biological 58: 91-99.

Jackson M L. 1973. Soil chemical analysis. New Delhi, Prentce Hall of India. Pvt. Ltd. 189p. 
Ortel J, Gintenreiter S and Nopp H. 1993. Metal bioaccumulation in a host insect (Lymantria dispar L., Lepidoptera) during development- ecotoxicological implications In: Ecotoxicology of metals in invertebrates Dallinger $\mathrm{R}$ and Rainbow P S (eds) 401- 425.

Pedersens A, Kristiansen E, Andersen R A and ZachariassenK E. 2008. Cadmium deposited in the gut content of larvae of the beetle Tenebrio molitor and involves a Cd-binding protein of the low cysteine type. Compendium Biochemistry Physiology Part C 148: 217-222.

Ramana S, Biswas AK, Kundu S, Saha JK and Yadav RBR. 2002. Effect of distillery effluent on seed germination in some vegetable crops. Bioresource Technology 82: 273-275.

Saravanamoorthy M D and Kumari R. 2005.Effect of cotton yarn dye effluent on physiological and biochemical content of peanuts and green gram. Biochemical cell Archs 5(1): 113-117.

Sharma R K, Agrawal M and Marshall F M. 2007.Heavy metal contamination of soil and vegetables I suburban areas of Varanasi, India. Ecotoxicology and Environmental Safety.66: 258-266.

Sheng Zhang Z, Guo Lu, Wang Q and Zheng D M. 2009. Mercury, cadmium and lead biogeochemistry in the soil-plant-insect system in Huludao City. Bulletin of Environmental Contamination and Toxicology 83(2): 255-259.

Sildanchandra W and Crane M. 2000. Influence of sexual dimorphism in Chironomus riparius Meigen on toxic effects of cadmium. Environmental Toxicology Chemistry19: 2309-2313.

Smith C E, Stam E M, Baas N, Hollander R and Van Gestel C A. 2004. Effects of dietary zinc exposure on the life history of the parthenogenetic springtail Folsomia candida (Collembola: Isotomidae). Environmental Toxicology Chemistry 23(7): 1719-24.

USEPA. Air Quality Criteria for Lead 2006. Final Report. U.S. Environmental Protection Agency, Washington, DC, EPA/600/R-05/144aF-bF, 2006.

Vogel W R. 1986. Heavy metal contamination of bark-beetles. EntomologiaExperimentaliset Applicata 42(3): 259269.

Xia S U N, Ying-Hua S H U, Wen-Cheng T A $\mathrm{N} \mathrm{G}$, Wang Q I, Qiang Z H O U and Guren Z. 2007. Nickel accumulation and its effects on the survival rate of Spodoptera litura F. under continuous nickel stress. Chinese Science Bulletin 52(14): 1957-1963.

Zheng- Tian Z, Zhang H U, Wang Q L, ZhenLing P I, Liang Z, Xia M I and Qing D U. 2011. Changes in developmental duration, starvation tolerance and cadmium content in Pirata sub piraticus (Araneae: Lycosidae) fed on diets with cadmium. Acta Entomologica Sinica 34: 43-46.

Zverera E, Serebrov V and Glupov V. 2003. Activity and heavy metal resistance of non specific esterases in leaf beetle, Chrysomela lapponica from polluted and unpolluted habitats. Compendium on Biochemistry Physiology, Pharmacology, Toxicology and Endocrinology 135: 38391.

\section{How to cite this article:}

Shreya Handa, Meena Thakur and Bhardwaj, S.K. 2018. Effect of Industrial and Distillery Effluents on Spodoptera litura. Int.J.Curr.Microbiol.App.Sci. 7(09): 3687-3693. doi: https://doi.org/10.20546/ijcmas.2018.709.458 